Historia i Polityka

Półrocznik poświęcony myśli politycznej i stosunkom międzynarodowym

Nr $10(17) / 201395-114$

DOI: http://dx.doi.org/10.12775/HiP.2013.014

Konrad Sebastian Morawski (Uniwersytet Rzeszowski)

\title{
Okoliczności budowy stosunków dyplomatycznych pomiędzy Polską a Jugosławią w 1918 roku
}

\author{
Circumstances of establishment of diplomatic relations \\ between Poland and Yugoslavia in 1918
}

Officially, diplomatic relations between Poland and Yugoslavia commenced mid-January 1919. However, representatives of both countries had established and nurtured close cooperation already in the last quarter of 1918. As a matter of fact, the Polish and Serbian nations established some forms of cooperation with in the mid-nineteenth century, when both sought to implement major policy objectives.

Circumstances surrounding the establishment of Polish-Yugoslavian diplomatic relations were reflected in the complicated political situation of both the Polish and Yugoslav peoples after the end of World War I. The present study focuses mainly on this particular issue and its aspects.

Słowa kluczowe: I wojna światowa, stosunki dyplomatyczne, Polska, Jugosławia Keywords: World War I, diplomatic relations, Poland, Yugoslavia

\section{Wstęp}

Celem artykułu jest omówienie tworzenia się stosunków dyplomatycznych pomiędzy Polską a Jugosławią ${ }^{1}$, które formalnie zostały nawiązane w połowie stycznia 1919 roku. Tymczasem nieformalne powiązania polsko-jugosłowiańskie wykształ-

1 W latach 1918-1929 oficjalną nazwą państwa jugosłowiańskiego było Królestwo Serbów, Chorwatów i Słoweńców. Następnie w rezultacie przewrotu dokonanego przez króla Aleksandra I w dniu 6 stycznia 1929 roku został uruchomiony proces przeobrażeń w państwie, którego jedną z konsekwencji było ustanowienie 3 października 1929 roku nazwy Królestwo Jugosławii. W podjętych rozważaniach autor wobec państwa jugosłowiańskiego zastosował zamiennie nazwy Królestwo SHS oraz Jugosławia. 
ciły się sensu largo już w pierwszej połowie XIX wieku, a sensu stricte w ostatnim kwartale 1918 roku. Tworzenie się tych powiązań odzwierciedlało po pierwsze próby zainteresowania sprawą polską polityków bałkańskich, które były podejmowane przez polskie środowiska emigracyjne w Paryżu, zaś po drugie dynamikę planu zjednoczenia narodów południowosłowiańskich prowadzonego przez serbską dynastię Karađorđeviciów. Obie strony - zarówno polska emigracja, jak i Karađorđeviciowie - zabiegały o zmianę mocarstwowych układów międzynarodowych, która miała doprowadzić do restauracji niepodległej Polski i utworzenia wielkiego państwa południowosłowiańskiego.

Rezultaty tych zabiegów uwidoczniły się w ścisłym kontekście budowy polskojugosłowiańskich stosunków dyplomatycznych, ponieważ w klimacie kończącej się wielkiej wojny realizacji doczekały się zarówno ideał państwa jugosłowiańskiego, jak i niepodległej Polski. Wokół tworzenia się struktur obu państw po I wojnie światowej zarysowały się pomiędzy nimi obszary współpracy leżące u podstaw przyjaźni pomiędzy Polską a Jugosławią w okresie międzywojennym. Klimat budowy tych stosunków był jednak uwarunkowany przez okoliczności, które odzwierciedlały niestabilną sytuację międzynarodową w 1918 roku.

W istocie u podstaw konstrukcji stosunków pomiędzy Polską a Jugosławią należy rozpoznać działalność ośrodków władzy, które jeszcze w 1918 roku roku przestały odgrywać istotną rolę i uległy dekompozycji. Chodzi o ekipy rządzące w Królestwie Polski i Państwie SHS, które zabiegały o nawiązanie wzajemnej współpracy. W każdym razie ich wkład w kształtowanie się relacji polsko-jugosłowiańskich nie został zaprzepaszczony i znajdował umocowanie w ścisłym procesie budowy stosunków dyplomatycznych pomiędzy II Rzeczpospolitą Polską a Królestwem SHS w grudniu 1918 roku. Wokół okoliczności tego procesu zostały zlokalizowane najważniejsze wątki omówione w tym artykule.

\section{Budowa stosunków dyplomatycznych pomiędzy Polską a Jugosławią w 1918 roku}

Genezę stosunków polsko-jugosłowiańskich sensu largo można rozpatrywać od pierwszej połowy XIX wieku. Wtedy bowiem, w okresie rywalizacji Karađorđeviciów i Obrenoviciów o prymat władzy w Księstwie Serbii, wykształciła się oparta na głównych założeniach jugoslawizmu koncepcja Wielkiej Serbii, która została zawarta w pochodzącym z 1944 r. Projekcie (Načertanije, trans. Haчepmaнuje)2.

2 I. Garašanin, Načertanije. Program spoljašne i nacionalne politike Srbije na kroncu 1844. godine, 1844. 
Autorem dokumentu był członek ustawobranitieli ${ }^{3}$ i ówczesny minister spraw wewnętrznych Księstwa Serbii Ilija Garašanin. Jednak duży wpływ na jego utworzenie wywarł czołowy przedstawiciel polskiej emigracji książę Adam Jerzy Czartoryski, który wziął udział w pracach nad koncepcją za pośrednictwem swoich agentów Michała Czajkowskiego oraz Františka Zacha .

Ponadto w latach trzydziestych XIX wieku wiodący działacz Hotelu Lambert udzielił poparcia dyplomatycznego księciu Aleksandrowi Karađorđeviciowi w zabiegach o zdetronizowanie zorientowanego proaustriacko Michała Obrenovicia. W ten sposób bez ryzyka można stwierdzić, że we wspominanym okresie wykształciły się bezpośrednie stosunki między polskim środowiskiem emigracyjnym a serbską dynastią Karađorđeviciów. Apogeum tych stosunków nastąpiło w okresie rządów Aleksandra Karađorđevicia w Księstwie Serbii w latach 1842-1858.

Plany wypracowane w serbskiej koncepcji zjednoczeniowej Słowian południowych nie miały szans powodzenia, ponieważ w 1858 roku ponownie władzę w Serbii objęła dynastia Obrenoviciów. Taki stan rzeczy wpłynął na wieloletnie utajnienie Projektu, a stosunki polskiego środowiska emigracyjnego z dynastią Karađorđeviciów w drugiej połowie XIX wieku traciły na znaczeniu w kontekście polsko-serbsko-jugosłowiańskim. Jednak nawet pomimo słabnącej pozycji w Belgradzie Polacy nie porzucili zainteresowania sprawą bałkańską, o czym świadczyła działalność polskich pracowników w ramach francuskiej służby konsularnej.

3 Ustawobranitieli byli grupą polityków, którzy domagali się od księcia Serbii Miloša Obrenovića przywrócenia zawieszonej przez niego konstytucji z 1835 roku i realizacji polityki zjednoczeniowej Słowian południowych. Wiodącymi przedstawicielami ustawobranitieli byli Toma VučićPerišić, Avram Petronijević, Stojan i Aleksa Simić, a także Ilija Garašanin. W następstwie działań tej grupy polityków w 1839 roku doszło do przewrotu w księstwie, którego główną konsekwencją było obalenie z książęcego tronu Miloša Obrenovića, a następnie w 1842 roku jego syna Michała. Wtedy też władzę w Księstwie Serbii objął Aleksander Karađorđević. W języku serbskim nazwa tej grupy polityków brzmiała ustavobranitelji (trans. yставобранитеsи) czyli w tłumaczeniu na pol-

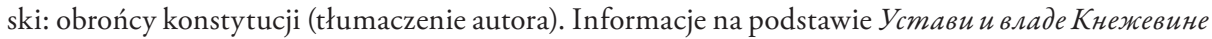
Србије, Краљевине Србије, Краљевине СХС и Кравевине. Jугославије (1835-1941), БеограА 1988, s. 71; D. Milošević, Ustavobranitelji u Kragujevcu oborili kneza Mihaila, Univerzitetska Biblioteka im. Svetozara Markovića (brak sygnatury i daty powstania dzieła).

4 Polscy badacze jednomyślnie wskazywali na polski wkład w koncepcję Wielkiej Serbii, aczkolwiek nie uczynił tego uznany badacz jugoslawizmu Dejan Djokić, który wyłączne autorstwo koncepcji przypisał Garašaninowi. Dla równowagi, żadnych wątpliwości w tej materii nie wykazywało grono wielu innych międzynarodowych historyków, takich jak Viktor Meier, Roland Robertson, Victor Roudometof oraz Vladislav B. Sotirović. Por. D. Djokić, Yugoslavism. Histories of a Failed Idea 1918-1992, London 2003, s. 17; V. Meier, Yugoslavia: A History of Its Demise, London 1999, s. 44-45; R. Robertson, V. Roudometof, Nationalism, Globalization, and Orthodoxy: The Social Origins of Ethnic Conflict in the Balkans, Greenwood 2001, s. 116-118; V. B. Sotirović, Creation Of The Kingdom Of Serbs, Croats and Slovens 1914-1918, Vilnius 2007, s. 11-12. 
Józef Kłoda Badowski przebywał w Belgradzie, zaś Leopold Moreau-Morawiecki w Mostarze. Obaj nieoficjalnie utrzymywali kontakty z Hotelem Lambert. Zresztą książę Czartoryski organizował tajne misje dyplomatyczne do Belgradu, które były obliczone na zainteresowanie sprawą polską. Po jego śmierci 15 lipca 1861 roku działalność w tym zakresie kontynuował Władysław Czartoryski.

Pomimo istotnie słabnącej pozycji Hotelu Lambertu na Bałkanach w drugiej połowie XIX wieku rezultaty współpracy Czartoryskich z Karađorđeviciami nie zostały w pełni zaprzepaszczone, ponieważ Projekt został odtajniony w 1906 roku, a więc trzy lata po objęciu władzy przez Piotra I Karađorđevicia w ówczesnym Królestwie Serbii ${ }^{6}$. Tekst Projektu został opublikowany na łamach czasopisma „Działać" (Delo, trans. Aeso) w artykule zatytułowanym Program spoljnje politike Ilije Garašanina na koncu 1844. godine ${ }^{7}$. Jego autorem był serbski historyk Milenko M. Vukićević. Wydźwięk publikacji na terytorium południowosłowiańskim należy określić jako istotny. Naród serbski w tym dziele określono gwarantem stabilizacji w Europie. Wokół państwa Karađorđeviciów usiłowano wytworzyć klimat orędownika zjednoczenia. Wtedy też w serbskiej polityce zagranicznej powrócono do koncepcji zjednoczeniowej Słowian południowych, a zatem odżyła kwestia zmiany statusu Serbów i innych narodów południowosłowiańskich w Austro-Węgrzech.

W stosunku do cesarsko-królewskiej monarchii roszczenia wyrażały również inne narody, które Henryk Batowski wyszczególnił zgodnie z kryterium grup interesu reprezentowanych według czterech typów dążeń. Otóż zainteresowane utrzymaniem statusu monarchii były oczywiście narody w niej rządzące, a więc Niemcy austriaccy oraz Węgrzy. Tymczasem o zmianę swojego położenia lub całkowite wyzwolenie z monarchii wnosili Czesi, Chorwaci, Słowacy oraz Słoweńcy, zaś kategoryczne dążenia separatystyczne wykazywały te narody zamieszkujące monarchię, których państwo macierzyste znajdowało się w najbliższym sąsiedztwie, a więc chodziło o Rumunów, Serbów oraz Włochów. Ostatnią grupę interesu tworzyły narody, które nie posiadały własnych państw, ale zmierzały do ich utworzenia wraz z rodakami żyjącymi poza granicami monarchii. W tej grupie należy wymienić Polaków oraz Ukraińców ${ }^{8}$.

5 Historia Dyplomacji Polskiej, red. L. Bazylow, t. III: 1795-1918, Warszawa 1982, s. 685-686.

6 Problematyka historii serbskiej, w tym przekształceń ustrojowych w XIX i XX wieku, była obiektem współczesnych badań wielu historyków, wśród których można wyróżnić m.in. Johna K. Coxa, Simę Ćirkovicia oraz Tima Judaha. Zob. J. K. Cox, The History of Serbia, Greenwood 2002; S. Ćirković, The Serbs, Wiley-Blackwell 2004; T. Judah, The Serbs: History, Myth and the Destruction of Yugoslavia, Yale 2009.

7 W polskim przekładzie: Program polityki zagranicznej Ilije Garašanina przy końcu 1844 roku (tłumaczenie autora).

8 H. Batowski, Rozpad Austro-Węgier 1914-1918, Kraków 1982, s. 27. 
Zatem dążenia zarówno narodów południowosłowiańskich, jak i Polaków wiązały się z tym samym celem, którym było odłączenie się od Austro-Węgier, a sprzyjające okoliczności do realizacji tych założeń nastąpiły w okresie I wojny światowej w latach 1914-1918. Wtedy bowiem wobec stopniowo słabnącego autorytetu władzy cesarsko-królewskiej na sile przybrały tendencje odśrodkowe narodów skupionych w monarchii, które wzmacniała działalność organizacji dyplomatycznych, takich jak m.in. Komitet Jugosłowiański oraz Komitet Narodowy Polski. Te organizacje były zainteresowane wyzwoleniem poszczególnych narodów spod berła habsburskiego.

Po stronie niezależności narodów skupionych w monarchii austro-węgierskiej opowiedziały się również światowe mocarstwa zrzeszone wśród państw Ententy. Otóż 8 stycznia 1918 roku Prezydent Stanów Zjednoczonych Ameryki Północnej Woodrow Wilson wygłosił orędzie, w którym w punkcie dziesiątym wyłożył potrzebę autonomicznego rozwoju narodów Austro-Węgier, zaś w punktach jedenastym oraz trzynastym odniósł się bezpośrednio do kwestii serbskiej i polskiej dając wyraz poparcia dążeniom niepodległościowym tych narodów ${ }^{9}$. Kilka miesięcy później, 3 czerwca 1918 roku, mocarstwa zachodnioeuropejskie Francja, Wielka Brytania oraz Włochy, utworzyły tzw. deklarację wersalską, której założenia uznawały niezależność Polaków, Czechosłowaków oraz Jugosłowian ${ }^{10}$. Znaczenie deklaracji było bezprecedensowe dla Karađorđeviciów, ponieważ w oficjalnym dokumencie w środowisku międzynarodowym wymieniono nazwę narodu Jugosłowian, o którego wykształcenie się zabiegano przecież na dworze króla Piotra I.

Uznanie amerykańskie oraz zachodnioeuropejskie było na tyle istotne dla wymienionych narodów, że umożliwiło im podjęcie zdecydowanych działań separatystycznych wobec Austro-Węgier w drugiej połowie 1918 roku. Jednocześnie

9 Punkt 10 orędzia brzmiał: „Ludom Austro-Węgier, którym pragniemy zapewnić miejsce wśród narodów, powinna zostać stworzona, najszybciej jak to tylko będzie możliwe, szansa autonomicznego rozwoju”, punkt 11: „Rumunia, Serbia i Czarnogóra muszą być ewakuowane; zwrócone im zostaną ich terytoria. Serbii zostanie przyznany wolny dostęp do morza, a stosunki między różnymi państwami bałkańskimi muszą zostać oparte na przyjacielskich porozumieniach, uwzględniających linie podziału wspólnot i narodowości, tak jak zostały one ustalone przez historię", zaś punkt 13: „Powinno zostać stworzone niepodległe państwo polskie, obejmujące terytoria zamieszkane przez ludność niezaprzeczalnie polską i któremu musi zostać zapewniony wolny dostęp do morza; niepodległość polityczna, gospodarcza oraz integralność terytoriów zamieszkanych przez tę ludność będą zagwarantowane przez konwencję międzynarodową". Skan oryginalnego orędzia Prezydenta Wilsona, zatytułowanego President Wilson's Fourteen Points (Czternaście punktów Prezydenta Wilsona), można odnaleźć m.in. na stronie internetowej brytyjskiego The National Archives, President Wilson's Fourteen Points, http://www.nationalarchives.gov.uk [odczyt z dn. 6.11.2013].

10 D. Perman, The Shaping of the Czechoslovak State. Diplomatic History of the Boundaries of Czechoslovakia, 1914-1920, Leiden 1962, s. 31-32. 
warto zauważyć, że podobne grupy interesu, które wykształciły się między Polską i Jugosławią a monarchią austrowęgierską nie były wyłącznie realizowane na poziomie stosunków multilateralnych. W połowie maja 1918 roku w Pradze odbyły się manifestacje przyjaźni polsko-czesko-jugosłowiańskiej, a na początku października tego samego roku wiodący politycy emigracyjni tych narodów wygłosili przemówienia, w których jasno deklarowano wspólne stanowisko antyhabsburskie. Następnie w dniach 22 i 23 października 1918 roku doszło w Paryżu do spotkania przedstawicieli polityków emigracyjnych Polski, Czechosłowacji oraz Jugosławii, które zakończyło się wymianą not odnoszących się do przyjaznej współpracy po wyzwoleniu spod berła austrowęgierskiego ${ }^{11}$. Należy jednak pamiętać, że reprezentacja narodu jugosłowiańskiego odnosiła się wyłącznie do Królestwa Serbii oraz polityków południowosłowiańskich zrzeszonych w Komitecie Jugosłowiańskim, którzy postulowali zjednoczenie z Serbią na warunkach dyktowanych przez Karađorđeviciów.

Zgoła odmienną wizję zjednoczenia narodów południowosłowiańskich zaproponowali decydenci, utworzonego 29 października 1918 roku Państwa Słoweńców, Chorwatów i Serbów. W sensie narodowościowym Państwo SHS obejmowało narody południowosłowiańskie - wyłączając grupę polityków skupionych w Komitecie Jugosłowiańskim - podległe w okresie przedwojennym monarsze austrowęgierskiemu. Państwo SHS według założeń twórców miało być odzwierciedleniem klasycznej idei jugoslawizmu opartej na zasadzie równouprawnienia narodów południowosłowiańskich. Właśnie w tym kontekście zakładano zjednoczenie z Królestwem Serbii, aczkolwiek wobec słabości międzynarodowej Państwa SHS proces zjednoczeniowy zdominowały założenia polityków serbskich z królewskiego rządu Nikoli Pašicia ${ }^{12}$.

Wprawdzie okres istnienia pierwszego państwa zjednoczonego w oparciu o ideę jugoslawizmu nie przekroczył pięciu tygodni, ale jego rola w genezie stosunków polsko-jugosłowiańskich sensu stricte została wyraźnie zaznaczona. Jeszcze na przełomie października i listopada 1918 roku władze Królestwa Polskiego z dużą atencją odnotowywały kolejne etapy procesu zjednoczeniowego narodów południowosłowiańskich.

11 H. Batowski, op. cit., s. 320-325.

12 W istocie już od okresu wojen bałkańskich w latach 1912-1913 realną władzę w Serbii sprawował książę regent Aleksander. Zob. H. Batowski, Między dwiema wojnami 1919-1939. Zarys historii dyplomatycznej, Kraków 2001, s. 14-15; D. Djokić, Elusive Compromise. A History of Interwar Yugoslavia, London 2007, s. 25-27; M. Waldenberg, Kwestie narodowe w Europie Środkowo-Wschodniej. Dzieje, idee, Warszawa 1992, s. 378; M. J. Zacharias, Komunizm, federacja, nacjonalizmy. System władzy w Jugostawii 1943-1991. Powstanie, przekształcenia, rozkład, Warszawa 2004, s. 20-21 i n. 
Na łamach wydawanej w ramach Monitora Polskiego Kroniki Polityczno-Społecznej 26 października 1918 roku wyłożono polskiej opinii publicznej informację o ukonstytuowaniu się Chorwackiej Rady Narodowej w Zagrzebiu, a cztery dni później poinformowano o wyposażeniu tej rady w siły zbrojne ${ }^{13}$. Następnie 5 listopada 1918 roku redaktorzy Monitora Polskiego rozważali różne warianty niejasnej przyszłości Królestwa Czarnogóry. Znamienne okazały się zacytowane słowa byłego ministra sprawiedliwości i spraw wewnętrznych w królewskim rządzie Czarnogóry Janko Spasojevicia ${ }^{14}$, który na łamach „Gazette de Lausanne” wskazał polityczny kurs obrany przez decydentów państwa, postulując potrzebę wcielenia Czarnogóry do Serbii, a także: „zjednoczenia narodu serbskiego z pobratymcami Chorwatami i Serbami i utworzenia niepodzielnego państwa demokratycznego" ${ }^{15}$. W poglądach głoszonych przez środowisko polityczne Spasojevicia wykształciła się aprobata dla przewodniej roli Serbii wśród narodów południowosłowiańskich ${ }^{16}$. Wobec tych poglądów a contrario redaktorzy cytowanego Monitora Polskiego słusznie zwrócili uwagę na niechęć Państwa SHS wobec politycznych aspiracji Serbii.

Do tej kwestii powrócono kolejnego dnia, bowiem w Kronice Polityczno-Społecznej nie zwlekano z przytoczeniem odezwy Rady Narodowej SHS do Narodu, w której jedynym wyrazicielem polityki państwa ustanowiono wspominaną radę. Ponadto wyłożono potrzebę utrwalenia jedności narodowej wszystkich Słoweńców, Chorwatów i Serbów w sensie etnograficznym oraz poparcia bytu państwowego SHS. W tej samej odezwie znalazło się również wezwanie skierowane do uczestników środowiska międzynarodowego o potrzebie uznania państwa. Taki stan rzeczy świadczył o intencji decydentów Państwa SHS ukierunkowanej na jego samodzielne funkcjonowanie,

13 Monitor Polski 1918, nr 186 i 189, Kronika Polityczno-Społeczna.

14 W cytowanym numerze Monitora Polskiego zostało przytoczone nazwisko Giorgja Sperojevica, ale ponad wszelką wątpliwość chodziło o wielkiego zwolennika bezwarunkowej unii Czarnogóry z Serbią Janko Spasojevicia, który podwójną funkcję ministerialną sprawował w okresie od 29 kwietnia 1916 roku do 4 stycznia 1917 roku. Od 4 marca 1917 roku Spasojević przebywał w Paryżu, gdzie z grupą innych byłych ministrów Królestwa Czarnogóry współtworzył Czarnogórski Komitet ds. Zjednoczenia, którego priorytety były zogniskowane wokół szybkiego przyłączenia Czarnogóry do Serbii na warunkach serbskich. Warto dodać, że Spasojević w dniu 25 października 1918 roku wszedł w skład Centralnej Egzekutywy Komitetu ds. Zjednoczenia Czarnogóry z Serbią i był jednym z głównych polityków czarnogórskich zaangażowanych w pomyślny przebieg procesu przyłączeniowego. Zob. S. Pavlović, Balkan Anschluss. The Annexation of Montenegro and the Creation of the Common South Slavic State, Purdue University 2008, s. 92, s. 147-149, s. 150-151, s. $158-160$.

15 Monitor Polski 1918, nr 195, Kronika Polityczno-Społeczna.

16 Klimat polityczny w Królestwie Czarnogóry u schyłku I wojny światowej nie został dotąd dostatecznie opisany w polskiej literaturze, a próbę wstępu do badań w tym zakresie podjąłem w Ukryty fragment czarnogórskiej historii: przyłączenie Czarnogóry do Serbii w 1918 roku, Sprawy Narodowościowe. Seria Nowa 2012, z. 41, s. 211-221. 
a w konsekwencji odejście lub przebudowę warunków procesu zjednoczeniowego z Serbią. Dynamizmu, rozpoczętemu procesowi utrwalania państwa południowosłowiańskiego, nadało ustanowienie wytycznych organizacyjnych Rady Narodowej SHS, które zostały opublikowane na łamach Kroniki Polityczno-Społecznej w dniu 9 listopada $1918 \mathrm{roku}^{17}$.

Aktywność Królestwa Polskiego względem problemu południowosłowiańskiego nie ograniczała się wyłącznie do biernych relacji. Prezydent Rady Ministrów Józef Świeżyński już 3 listopada 1918 roku przesłał do Rady Narodowej w Zagrzebiu pozdrowienia oraz życzenia pomyślności ${ }^{18}$. Taki gest oznaczał uznanie dyplomatyczne dla świeżo wykształconego Państwa SHS. Nosił też znamiona nieostrożności, ponieważ mógł narazić Królestwo Polskie na nieprzychylność zarówno ze strony Włoch, jak i Serbii, które były zainteresowane przejęciem części terytoriów Państwa SHS, a więc i brakiem jego międzynarodowej legitymizacji. Tymczasem odpowiedź ze strony słoweńsko-chorwacko-serbskiej dotarła na terytoria polskie 12 listopada 1918 roku. W dokumencie została wyrażona gotowość do nawiązania stosunków dyplomatycznych Państwa SHS z niepodległą Polską, ale jego polityczne znaczenie było trudne do rozstrzygnięcia ${ }^{19}$. Wszakże $\mathrm{w}$ tym czasie w Polsce funkcjonowało kilka ośrodków władzy, bo poza chylącą się ku upadkowi Radą Regencyjną Królestwa Polskiego swoje struktury wykształciły krakowska Polska Komisja Likwidacyjna, lubelski Tymczasowy Rząd Ludowy Republiki Polskiej oraz Naczelna Rada Ludowa na terytorium byłego zaboru pruskiego, a konsolidację państwa dodatkowo utrudniały Rady Delegatów Robotniczych. Natomiast na arenie międzynarodowej interesy polskie reprezentował cieszący się zaufaniem państw Ententy Komitet Narodowy Polski w Paryżu, który był przez Francję traktowany jako faktyczny polski rząd ${ }^{20}$.

17 Monitor Polski 1918, nr 196 i 199, Kronika Polityczno-Społeczna.

18 Podobny gest został również wyrażony w stosunku do Budapesztu i Pragi, Monitor Polski 1918, nr 192, Dział urzędowy.

19 Dokument był adresowany do zdymisjonowanego 3 listopada 1918 roku Prezydenta Rady Ministrów Józefa Świeżyńskiego oraz zdymisjonowanego 4 listopada 1918 roku ministra spraw zagranicznych Stanisława Głąbińskiego, aczkolwiek znalazł się w posiadaniu Polskiej Komisji Likwidacyjnej, Monitor Polski 1918, nr 201, Telegramy.

20 W dniu 14 listopada 1918 roku Rada Regencyjna przekazała władzę Józefowi Piłsudskiem i tego dnia uległa rozwiązaniu, wspierany przez Józefa Piłsudskiego lubelski rząd formalnie upadł 17 listopada 1918 roku. Następnego dnia, również z poparciem Piłsudskiego, został powołany rząd Jędrzeja Moraczewskiego, a Piłsudski ogłosił się 22 listopada 1918 roku Tymczasowym Naczelnikiem Państwa. Rząd Moraczewskiego został uznany przez Polską Komisję Likwidacyjną, ale wątpliwości wyrażali działacze KNP. Od listopada 1918 roku do stycznia 1919 roku między KNP a rządem Moraczewskiego trwały rozmowy porozumiewawcze. Rząd Moraczewskiego upadł 16 stycznia 1919 roku, a jego miejsce zajął uformowany tego dnia gabinet Ignacego Paderewskiego, który stanowił wyraz porozumienia pomiędzy KNP a Warszawą. Rady Delegatów Robotniczych uległy rozwiązaniu 
W tle skomplikowanego procesu ustanowienia władz centralnych w Polsce stosunki z narodami południowosłowiańskimi przebiegały na różnych poziomach, ponieważ po stronie polskiej kwestie jugosłowiańskie zwracały uwagę zarówno Komitetu Narodowego Polski, jak i Polskiej Komisji Likwidacyjnej oraz rządu Moraczewskiego. Jeszcze w przededniu odzyskania przez Polskę niepodległości płk Edward M. House, pełniący ówcześnie funkcję doradcy prezydenta Woodrowa Wilsona, w rozmowie z przedstawicielami KNP Maurycym Zamoyskim i Franciszkiem Fronczakiem dał wyraz konieczności wypracowania wspólnego stanowiska Polaków z Czechami, Rumunami, Jugosłowianami i Litwinami w kontekście projektowanej powojennej konferencji pokojowej ${ }^{21}$. Następstwem tej sugestii było oddelegowanie profesora Stanisława Grabskiego do stosunków z Czechosłowakami, Rumunami i Jugosłowianami, co zostało zatwierdzone podczas posiedzenia KNP zwołanego 11 listopada 1918 roku w Paryżu². Grabski już sześć dni później na jednym z kolejnych posiedzeń KNP zwrócił uwagę na potrzebę wysłania polskiej misji wojskowej do Serbii, a także wystąpił z propozycją ustanowienia Komitetu Narodowego na Bałkanach i wysunął kandydaturę Jana Zamorskiego do objęcia nad nim przedstawicielstwa ${ }^{23}$.

W odpowiedzi przesłanej przeszło dwa tygodnie później w dniu 29 listopada 1918 roku Zamorski stwierdził, że jego obecność na Bałkanach byłaby bezprzedmiotowa, bowiem w Zagrzebiu z ramienia rządu Moraczewskiego przebywa chargé d'affaires Marceli Szarota ${ }^{24}$. Postawa Zamorskiego nie była bezzasadna w kontekście porozu-

na początku stycznia 1919 roku, a Naczelna Rada Ludowa zakończyła działalność w czerwcu 1919 roku decyzją o uznaniu rządu Paderewskiego.

2115 listopada, notatka Sekretariatu Generalnego KNP do przedstawiciela Komitetu w Londynie o sprawach bieżących, Polskie dokumenty dyplomatyczne 1918 listopad-grudzień, red. S. Dębski, Warszawa 2010 [dalej: PDD 1918], s. 26.

2211 listopada, protokół posiedzenia KNP w Paryżu, PDD 1918, s. 3-4.

23 Jan Zamorski był odpowiednim kandydatem do objęcia przedstawicielstwa Komitetu Narodowego na Bałkanach. W dniu otrzymania telegramu z KNP przebywał w Padwie, gdzie funkcjonowała Międzysojusznicza Komisja Propagandy, której priorytety były zogniskowane wokół „szerzenia propagandy wśród austriackich żołnierzy”, co miało na celu wzbudzenie nieufności i osłabienie morale armii austro-węgierskiej przez odwoływanie się do czynników narodowych. Obok Zamorskiego w skład Komisji weszli m.in. Chorwat, Serb i Słoweniec, Protokół 155. Posiedzenia Komitetu Narodowego Polskiego w Paryżu 17 listopada 1918, O Niepodległa i Granice. Komitet Narodowy Polski. Protokoty posiedzeń 1917-1919, red. A. Koseski i inni, Warszawa-Pułtusk 2007, s. 600-602; J. Szablicka-Żak, M. Janicki, Nauczyciel, żotnierz, polityk..., różne oblicza Jana Zamorskiego, Gronie 2010, nr 9, s. 8-10.

24 W 2010 roku w październikowym wydaniu niezależnego magazynu kulturalnego „Panorama Polska” kierownik Referatu do Spraw Konsularnych Ambasady Polski w Zagrzebiu Paweł Sokołowski stwierdził, że polsko-chorwackie stosunki dyplomatyczne sięgają 1918 roku, a pierwszym konsulem RP w Zagrzebiu był Gabor Ungar. Taki stan rzeczy świadczył o tym, że rząd Daszyńskiego lub Moraczewskiego obok Marcelego Szaroty wysłał do Zagrzebia również tajemni- 
miewawczym pomiędzy KNP a rządem warszawskim. Ponadto jego obecność w Zagrzebiu mogłaby zostać odebrana niejednoznacznie przez władze Państwa SHS, które przecież rząd polski widziały w Warszawie. Niemniej na etapie, w którym Zamorski otrzymał propozycję wyjazdu na Bałkany jego odmowna postawa mogła być zinterpretowana jako nieprzychylna wobec niezależnej od Warszawy polityki prowadzonej przez KNP.

Działalność Szaroty w Zagrzebiu mogła wzbudzać wątpliwości, co do wizji rządu Moraczewskiego odnoszącej się do przyszłości Państwa SHS i Królestwa Serbii. Tenże rząd za pośrednictwem wspominanego dyplomaty nieoficjalnie organizował podstawy współpracy dyplomatycznej z Państwem SHS, a takowych kroków bynajmniej nie poczyniono w tym okresie w stosunku do Królestwa Serbii. Co prawda w połowie listopada 1918 roku w ramach Polskiej Komisji Likwidacyjnej zdecydowano o wysłaniu do Belgradu dwóch przedstawicieli w osobach profesorów Tadeusza Stanisława Grabowskiego oraz Władysława Konopczyńskiego, aczkolwiek ich misja nie była związana ze stosunkami polsko-serbskimi. Uwagę PKL przykuwał dowódca Armii Wschodniej Louis Franchet d'Esperay, któremu Grabowski i Konopczyński mieli wyłożyć problemy sprawy polskiej ze szczególnym naciskiem na kwestię konfliktu jaki miał miejsce w Galicji Wschodniej ${ }^{25}$.

Jednak wizyta krakowskich profesorów wywarła niespodziewanie szeroki i entuzjastyczny oddźwięk wśród społeczeństwa serbskiego. Otóż belgradzki dziennik „Pravda” poinformował, że celem polskiej misji było zawarcie ścisłego kontaktu z południowymi Słowianami, a Polacy dążą do federacji wszystkich Słowian. Taki

czego Gabora Ungara. W korespondencji, którą podjąłem z konsulem Sokołowskim okazało się, że chodziło o doktora Šandora Ungara, pełniącego funkcję tymczasowego konsula RP w Zagrzebiu w 1919 roku. Dr Šandor Ungar urodził się prawdopodobnie w 1861 roku we Lwowie, a zmarł 20 maja 1920 roku w Zagrzebiu. Zdaniem Konsula Sokołowskiego był: „cenionym słowianofilem, autorem kilku publikacji, w tym Le spectre l'ancienne slavic occidentale (Quelques remarques a l'occasion du congres de la Paix)". W trakcie pełnienia urzędu w Zagrzebiu otrzymał nominację na stanowisko konsula w Lublanie, aczkolwiek tuż przed wyjazdem do Słowenii zmarł na atak serca. Spoczął na chorwackim cmentarzu Mirogoj, na którym w wyniku starań Ambasady RP w Zagrzebiu 22 lipca 1999 roku została odsłonięta ku jego czci tablica pamiątkowa w Alei Zasłużonych, Polacy $w$ Chorwacji. Leszek Wątróbski rozmawia z Pawtem Sokołowskim, kierownikiem referatu do spraw konsularnych ambasady RP $w$ Zagrzebiu, Panorama Polska, październik 2010, nr 10 (204), s. 14; oraz korespondencja z kierownikiem Referatu ds. Konsularnych Ambasady RP w Chorwacji Pawłem Sokołowskim (w prywatnych zbiorach autora).

25 Wysłanników PKL przyjął dowódca francuskiej armii na froncie bałkańskim generał Paul Prosper Henrys, który polskie problemy wyłożone przez Grabowskiego i Konopczyńskiego przesłał telegraficznie do generała d'Esperaya, a ten następnie w porozumieniu z KNP w Paryżu zobowiązał się telegraficznie zawiadomić konferencją wersalską w odniesieniu do polskiej sprawy. Taki stan rzeczy dobitnie świadczył o niepodważalnej pozycji i autorytecie KNP w procesie kształtowania się władz niepodległej Polski. 
stan rzeczy był następstwem wizyty Grabowskiego i Konopczyńskiego, którą złożyli rektorowi Uniwersytetu w Belgradzie Bogdanowi Gavriloviciowi. W dyskusji odnoszącej się do tematów politycznych uczestniczyła też duża grupa polityków serbskich, czarnogórskich, bośniackich, hercegowińskich, slawońskich i z okolic Triestu ${ }^{26}$.

Polskie władze w Warszawie doniesień „Pravdy” nie zdementowały, ale też okoliczności polityczne przełomu listopada i grudnia 1918 roku związane z finalizacją procesu zjednoczeniowego Państwa SHS i Królestwa Serbii wcale takiego dementi nie wymagały. Tym bardziej, że gdy 21 listopada 1918 roku do ministerstwa spraw zagranicznych w Warszawie wpłynęła notatka od polskiego przedstawicielstwa w Bernie stało się rzeczą jasną, iż proces zjednoczeniowy wspomnianych państw pod serbskim przewodnictwem był nieunikniony. W notatce znalazła się informacja, że wśród planowanych uczestników konferencji pokojowej po stronie jugosłowiańskiej przewiduje się reprezentację w osobie Ante Trumbicia, a więc zwolennika zjednoczenia Państwa SHS z Królestwem Serbii ${ }^{27}$. W praktyce oznaczało to brak legitymizacji dla pierwszego z wymienionych państw ze strony kluczowych uczestników środowiska międzynarodowego, a zatem konieczność budowy po stronie polskiej struktur dyplomatycznych w Belgradzie. Również działacze KNP zdawali sobie sprawę z nieuchronności procesu zjednoczeniowego. W konsekwencji doprowadziło to do ograniczenia wysiłków dyplomatycznych wobec Państwa SHS.

Rychłe zjednoczenie Państwa SHS i Królestwa Serbii zostało potwierdzone w telegramie, który polski rząd otrzymał z Belgradu w dniu 25 listopada 1918 roku $^{28}$. Poinformowano $\mathrm{w}$ nim o podjętych decyzjach $\mathrm{w}$ sprawie zjednoczenia pomiędzy Serbią i Czarnogórą a „krajami południowosłowiańskimi”. Szczegóły procesu zjednoczeniowego miały zostać wypracowane w kolejnych dniach, ale już wtedy nie było tajemnicą, że zjednoczone państwo południowosłowiańskie będzie rządzone pod berłem Piotra I Karađorđevicia ${ }^{29}$. W ten sposób dziewiętnastowieczne serbskie dążenia zjednoczeniowe doczekały się realizacji wraz z utworzeniem 1 grudnia 1918 roku Królestwa Serbów, Chorwatów i Słoweńców. Forma tego wielonarodowego państwa stanowiła nawiązanie do koncepcji Aleksandra Karađorđevicia, a w konsekwencji przynajmniej częściową realizację założeń koncepcji wielkoserbskiejº ${ }^{30}$ Warto jedno-

26 Monitor Polski 1918, nr 218 i 219, Telegramy.

2721 listopada, notatka przedstawicielstwa w Bernie dla MSZ w sprawie konferencji pokojowej, [w:] PDD 1918, s. 60-61.

28 Monitor Polski 1918, nr 218, Telegramy.

29 Koronacja realnego władcy Królestwa SHS księcia regenta Aleksandra nastąpiła po śmierci króla Piotra I, a więc 16 sierpnia 1921 roku.

30 Zob. D. Djokić, Elusive..., s. 30-31; P. Eberhardt, Przemiany demograficzno-etniczne na obszarze Jugostawii w XX wieku, Lublin 2005, s. 25; M. Waldenberg, op. cit., s. 378; W. Walkiewicz, Jugostawia, Warszawa 2009, s. 39-42; M. J. Zacharias, op. cit., s. 20-21 i inni. 
cześnie zauważyć, że treść wspominanego telegramu mogła wzbudzać wątpliwości co do czarnogórsko-serbskiego statusu politycznego, ponieważ świadczyła o jednomyślnym ośrodku decyzyjnym Serbii i Czarnogóry, a sam proces przyłączeniowy pomiędzy tymi państwami zakończył się dopiero 26 listopada 1918 roku, a więc dzień po nadesłaniu telegramu. Właśnie z tego powodu nazwa „Czarnogóra” została w ogóle wymieniona, ponieważ po ostatecznym wcieleniu tego państwa do Serbii, a następnie do Królestwa SHS owa czarnogórskość została wchłonięta przez naród serbski ${ }^{31}$.

O ile przyszłość zjednoczonego państwa południowosłowiańskiego w drugiej połowie listopada 1918 roku była już jasna, o tyle nierozwiązane pozostawały kwestie wojskowe i mobilizacyjne, ponieważ wraz z rozpadem i rozczłonkowaniem monarchii austro-węgierskiej w niejasnym położeniu znaleźli się zarówno polscy wojskowi, jak i ludność cywilna, którzy przebywali poza granicami kształtującej się Polski. W szczególnie trudnej sytuacji znajdowali się Polacy na terytorium Państwa SHS, bowiem aspiracje względem słoweńskiej części jeszcze na początku listopada 1918 roku wyrażał cesarz Karol I Habsburg. Jednak o wiele groźniejsze były plany królewskiego rządu włoskiego kierowanego od 23 października 1917 roku przez Vittorio Emanuele Orlando. Polityk przy udziale ministra spraw zagranicznych Sidneya Sonnino oraz członków rządu dążył do zajęcia części terytoriów, które weszły w skład Państwa SHS ${ }^{32}$.

31 Naród czarnogórski w oficjalnych statystykach demograficznych został po raz pierwszy uwzględniony w 1948 roku, a więc już w realiach komunistycznej Jugosławii. Dane z wcześniejszego okresu nie uwzględniały odrębności narodowej Czarnogórców, którzy byli traktowani jako Serbowie. Taki stan rzeczy potwierdzają badania Aleksandra Rakovicia oraz Piotra Eberhardta. Warto dodać, że wybitny polski uczony w swojej pracy z 2005 roku Przemiany demograficzno-etniczne na obszarze Jugosławii $w X X$ wieku w części statystycznej badań powołał się na niekwestionowany autorytet w dziedzinie problematyki etnicznej i narodowościowej na Bałkanach profesora Károly Kocsisa z Węgierskiej Akademii Nauk. Należy jednak za profesorem Eberhardtem zauważyć, że nawet mimo nieuwzględniania Czarnogórców w oficjalnych statystykach demograficznych w tym okresie istniały już przesłanki wpływające na poczucie czarnogórskiej tożsamości narodowej, takie jak własna historia, prawo, religia, niepodległość, a także kultura, w której nie bez znaczenia były poetyckie inklinacje króla Mikołaja I Mirkovicia Petrovicia-Njegoša. Zresztą tenże monarcha w okresie istnienia Królestwa Czarnogóry utrwalił w swoich wypowiedziach istnienie par excellence narodu czarnogórskiego, choćby w deklaracji przystąpienia do I wojny światowej, P. Eberhardt, op. cit., s. 103-108; A. Raković, Nacionalni identitet u Crnoj Gori, Pravda, Februar 2004, s. 12.

32 Sidney Sonnino sprawował urząd ministra spraw zagranicznych Królestwa Włoch już w rządzie Antonio Salandry, który 26 kwietnia 1915 roku podpisał z państwami Ententy traktat w Londynie gwarantujący jego państwu przejęcie po wojnie pewnej części terytoriów monarchii austro-węgierskiej. Apetyty Włochów znacząco rozszerzyło rozgromienie na przełomie października i listopada 1918 roku floty austro-węgierskiej przez słynną królewską flotę Regia Marina. W wyniku tego starcia austrowęgierski generał Viktor Weber Edler von Webenau wraz z innymi wojskowymi został zmuszony do podpisania zawieszenia broni pomiędzy Austro-Węgrami a Włochami, które nastąpiło 3 listopada 1918 roku w Villa Giusti. W tym porozumieniu zagwaranto- 
Problem włoskiego natarcia starał się rozwiązać 8 listopada 1918 roku ppłk Josip Svetič, który w imieniu dowództwa wojskowego w Lublanie wystosował okólnik ${ }^{33}$, wzywający wszystkich oficerów żandarmerii oraz żandarmów południowosłowiańskich narodowości zatrudnionych na terytoriach wojennych ze wskazaniem Bałkanów, Polski, Rosji, Ukrainy oraz Wenecji do bezpośredniego stawienia się lub przekazania pisemnego raportu sytuacyjnego wskazanemu dowództwu. W klimacie nagłej mobilizacji nowo uformowanej armii Państwa SHS Svetič odniósł się również do wojskowych innych narodowości, w tym rzecz jasna Polaków, chcących służyć w armii południowosłowiańskiej lub opuścić granice państwa. Dla obu wariantów zachowań przewidziano w okólniku odpowiednie procedury $^{34}$.

Sytuacja polskich wojskowych w Lublanie została również zauważona w Naczelnym Dowództwie Armii Serbskiej, która wobec nasilającego włoskiego natarcia w głąb słoweńskiej części Państwa SHS została postawiona w stan najwyżej gotowości. W raporcie sytuacyjnym sporządzonym 13 listopada 1918 roku płk Dušan Simović3 35 zwrócił uwagę na obecność polskiej baterii w Lublanie. Jego uwadze nie uszły też będące w toku formowania dwie polskie baterie w Zagrzebiu oraz kolejna w Lublanie. Pułkownik wyraził jednocześnie znacząco brzmiące zdanie, iż modli się o to aby rząd włoski zatrzymał swoje wojska, ponieważ Królestwo Serbii staje w obliczu nieuniknionego konfliktu ${ }^{36}$.

wano Włochom terytoria austrowęgierskie, które znacząco rozszerzały powojenne zdobycze tego państwa, właśnie m.in. o Istrię oraz dużą część Dalmacji, a więc terytoria już wtedy wchodzące w skład terytorialny Państwa SHS.

33 Uradni list Narodne vlade SHS v Ljubljani, 1918, št. 4, Okrožnica orožniškega poveljništva v Ljubljani.

34 Ibidem.

35 Sylwetka Dušana Simovicia wymaga przybliżenia ze względu na jego działalność w ostatnich latach istnienia Królestwa Jugosławii. W okresie 1936-1938 Dušan Simović w stopniu generała lotnictwa objął dowództwo nad Jugosłowiańskimi Królewskimi Siłami Powietrznymi, zaś w latach 1938-1941 sprawował funkcję Szefa Sztabu Generalnego (pomijając krótką przerwę w 1940 roku kiedy tymczasowo Szefem Sztabu mianowano Petara Kosicia). Ten sam wojskowy, który w 1918 roku wyrażał zatroskanie z powodu zagrożenia królewskiej integralności Serbii niemal ćwierć wieku później raz jeszcze udowodnił swoje przywiązanie do ustroju królewskiego. Wszakże z błogosławieństwem nie mającego jeszcze osiemnastu lat księcia regenta Piotra II Karađorđevicia stanął na czele przeprowadzonego 27 marca 1941 zamachu stanu na rząd Dragišy Cvetkovicia, który dwa dni wcześniej pod przewodnictwem księcia regenta Pawła Karađorđevicia podpisał porozumienie o przystąpieniu Jugosławii do państw Osi. Urząd premiera po zamachu stanu objął właśnie Simović, zaś pozbawiony władzy książę Paweł udał się na emigrację i już nigdy więcej nie powrócił do Jugosławii.

36 Pukovnik D. Simović - Srpskoj vrhovnoj komandi, Zagreb 13 novembra 1918, Jugoslavija 1918-1988. Tematska Zbirka Dokumenata, red. B. Petranović, M. Zečević, Beograd 1988, s. 95. 
Tymczasem po stronie Polski zainteresowanie losami polskich wojskowych i ludności cywilnej na terytorium Państwa SHS wyrażali działacze KNP oraz generalicja, która z komitetem współpracowała. Do jego siedziby, 17 listopada 1918 roku, dostarczono list Agentury Rządu Polskiego w Lublanie, zaadresowany do dowódcy Armii Polskiej we Francji generała Józefa Hallera, w którym wobec trudnego położenia Polaków proszono o szybką interwencję militarną i aprowizacyjną. Generał zareagował niezwłocznie. Następnego dnia do KNP został przekazany podpisany przez niego list, w którym prosił Komitet o „poczynienie kroków u rządu francuskiego" ukierunkowanych na wysłanie podporucznika Stanisława Kozakiewicza do Lublany. Celem jego misji miało być nawiązanie współpracy ze stacjonującym w Lublanie kapitanem Leonem Bulowskim, a następnie utrzymanie łączności z Armią Polską i skupienie Polaków w Państwie SHS ${ }^{37}$. Chodziło o uporządkowanie kwestii polskiej na Bałkanach, której nie służyły samodzielne próby przedostania się do kraju po stronie zdezorientowanych Polaków, ani tym bardziej uczestnictwo w zaostrzającym się konflikcie włosko-południowosłowiańskim.

Ekspansywne aspiracje Włochów zostały nieco ostudzone wraz z pomyślnym zakończeniem negocjacji pomiędzy Królestwem Serbii a Państwem SHS. Francuski dziennik „L’Humanite” już 26 listopada 1918 roku podał informację o przejęciu przez Serbów terytoriów południowosłowiańskich na mocy porozumienia obu państw. Taki stan rzeczy bynajmniej nie zakończył sporu włosko-południowosłowiańskiego, który został we wiodących częściach rozstrzygnięty dopiero wraz z podpisaniem 12 listopada 1920 roku traktatu w Rapallo ${ }^{38}$, ale uchronił większość słoweńskich terytoriów Państwa SHS przed okupacją włoską. Trzeba mieć jednak na uwadze, że w przeszło dwuletnim konflikcie strona włoska stoso-

37 Treść protokołu 155 potwierdza, że autorem listu była „komenda wojskowa polska w Lublanie", aczkolwiek autorzy publikacji O Niepodległa... zwrócili uwagę, że brakuje danych na temat takiej komendy w Lublanie. Autorzy przypuszczają, iż mogło chodzić o komendę polską w Lublinie, aczkolwiek list generała Hallera do KNP datowany na 18 listopada 1918 roku wskazuje iż w Lublanie była zorganizowana Agentura Polskiego Rządu. Zatem przedstawicielom tej placówki należy przypisać autorstwo listu, o którym była mowa w protokole 155, O Niepodlegta..., s. 600-602; 18 listopada, list naczelnego dowódcy Armii Polskiej we Francji do KNPW w Paryżu w sprawie noty Józefa Piłsudskiego, [w:] PDD 1918, s. 41-41.

$38 \mathrm{Na}$ mocy postanowień traktatowych Włochom przekazano całe terytorium tzw. Pobrzeża Austriackiego oraz część terytoriów Księstwa Krainy, Wewnętrznej Krainy i Górnej Krainy, a także miasto Zadar i dwie dalmatyńskie wyspy Lastovo i Palagruža. Ponadto ustanowiono tzw. Wolne Miasto Fiume, które jednak na mocy Traktatu Rzymskiego z 27 listopada 1924 roku zostało rozwiązane i pomijając Sušak włączone do terytoriów Włoch. W każdym razie na mocy ustaleń paryskich zatwierdzonych 10 lutego 1947 roku miasto powróciło do Jugosławii. Współcześnie, nie włączając Włoch i Węgier, zdecydowana większość uczestników środowiska międzynarodowego stosuje nazwę Rijeka. 
wała liczne prowokacje względem Państwa SHS, a później Królestwa SHS. Należy wspomnieć choćby o lądowaniu włoskich sił powietrznych w grudniu 1918 roku w Splicie i Zadarze oraz o aresztowaniu byłego deputowanego do austriackiego Reichsratu i redaktora naczelnego pisma „Narodni List” księdza Juraja Biankiniego $^{39}$. W grudniu Włosi wraz z Węgrami prowadzili w Rijece akcję propagandową przeciwko Chorwatom. Poszczególne etapy konfliktu były często relacjonowane na łamach Monitora Polskiego ${ }^{40}$.

Ostatecznie kwestie demobilizacyjne odnoszące się do terytoriów słoweńskich w ramach zjednoczonej Jugosławii zostały uregulowane poprzez oświadczenie o organizacji usług w sprawie demobilizacji materiałów z dnia 16 grudnia 1918 roku ${ }^{41}$, podpisane przez prezesa Rządu Narodowego SHS w Lublanie Josipa Pogačnika $^{42}$. W dokumencie nakreślono, że wobec dużej liczby interesantów przede wszystkim ze strony Czechosłowacji, Polski, Węgier i Austrii ustanawia się Biuro Transformacji Gospodarczej w Lublanie jako zwierzchni organ do załatwiania spraw demobilizacyjnych. W oświadczeniu stwierdzono, że pierwszeństwo w załatwianiu spraw nadaje się narodom zrzeszonym w Królestwie SHS, następnie Polsce i Czechosłowacji, a w dalszej kolejności innym państwom. Taki gest należało traktować jako akt dobrej woli w ramach polsko-jugosłowiańskiej i czechosłowacko-jugosłowiańskiej przyjaźni.

Zresztą kilka dni wcześniej, 13 grudnia 1918 roku, symboliczny gest na poziomie społeczno-intelektualnym wystosowali również Polacy, a ściślej polscy

39 W dniu 16 grudnia 1918 roku na łamach Monitora Polskiego poinformowano o aresztowaniu Juraja Biankiniego oraz ,jego brata, byłego posła do parlamentu austrjackiego”. Tymczasem chodziło o jedną osobę. Wśród czterech braci Biankinich największy posłuch uzyskał najmłodszy z nich o imieniu Ante. Ten znany chorwacki chirurg i socjolog kryminalistyki zajmował się również polityką, ale od 1898 roku przebywał na emigracji w USA oraz Wielkiej Brytanii, gdzie w ramach różnych organizacji wyrażał swoje poparcie dla zjednoczenia Słowian południowych. Tymczasem Juraj rzeczywiście zasiadał w Reichsracie w latach 1911-1914 z ramienia dalmatyńskiej Partii Prawa. Pozostali bracia Biankini nie angażowali się w politykę. Petar Luka był agronomem, zaś Dinko kapitanem statku.

40 Monitor Polski 1918, nr 230, 233 i 236, Kronika polityczno-społeczna, Ostatnia poczta i Telegramy.

${ }_{41}$ Uradni list Narodne vlade SHS v Ljubljani, 1918, št. 26, Razglas Narodne vlade SHS v Ljubljani o ureditvi službe z demobilizacijskim materialom.

42 Trzeba zauważyć, że Rada Narodowa Słowenii została rozwiązana dopiero 20 stycznia 1919 roku. W jej miejsce utworzono w pełni zależny od Belgradu Prowincjonalny Rząd Słowenii, ale podział administracyjny Królestwa SHS został w całości usystematyzowany dopiero na mocy uchwalonej 28 czerwca 1921 roku tzw. konstytucji widowdańskiej, której postanowienia wprowadziły 33 jednostki administracyjne o nazwie oblasty (tłumaczone w języku polskim jako prowincje). Te przeobrażenia pociągnęły za sobą również zmiany w nazwie dzienników urzędowych i innych aktów prawnych odnoszących się do królewskiego terytorium. 
pisarze, intelektualiści oraz działacze polityczni, którzy we wzniosłej odezwie zaadresowanej do pisarzy czeskich, słowackich, słoweńskich, serbskich i chorwackich dokonali rozliczenia z trudną przeszłością, co ważne określoną jako wspólną, a także wyrazili solidarność wobec uciskanych narodów słowiańskich oraz przekazali pełne patosu pozdrowienia, będące zapowiedzią wolności opartej na wzajemnej przyjaźni ${ }^{43}$.

Bez ryzyka można stwierdzić, że stosunki pomiędzy polskimi a innymi słowiańskimi inteligentami wykraczały ponad sztywne struktury państwowości, aczkolwiek zacytowana odezwa miała ważne znaczenie pod względem uznaniowym dla powojennego porządku politycznego. Wyrazem gestu polskich pisarzy była legitymizacja zarówno niepodległej Polski, jak i Królestwa SHS (oraz Czechosłowacji) ze strony inteligencji. Stanowiło to ważny element w budowie poczucia nierozerwalności nowo powstałych państw, choć jednocześnie wyposażało narody $\mathrm{w}$ nich zrzeszone $\mathrm{w}$ atrybuty tożsamości narodowej. Utwierdziło także w przekonaniu o konieczność istnienia powojennych państw wielonarodowych, bowiem odezwa została skierowana nie do Jugosłowian i Czechosłowaków. Jej adresatami byli Serbowie, Chorwaci, Słoweńcy, Czesi i Słowacy czyli narody zrzeszone w państwach, których władze zakładały wykształcenie się owych, skądinąd sztucznych narodów Jugosłowian i Czechosłowaków. Z pewnością dla zachowania politycznej równowagi w odezwie nie zostali wyszczególnieni pisarze z Bośni, Hercegowiny, Czarnogóry oraz Macedonii, co dodatkowo utwierdza w przekonaniu o jej wymowie politycznej ${ }^{44}$.

Trzy dni po tym wydarzeniu redaktorzy Monitora Polskiego za pośrednictwem Lublańskiego Biura Prasowego poinformowali o uformowaniu się pierwszego rządu Królestwa SHS, ale informacja, która dotarła do Polski zawierała błędy. Polską opinię publiczną poinformowano, że królewski rząd został utworzony 15 grudnia 1918 roku,

43 Warto zacytować fragment tej odezwy: „W tej uroczystej chwili naszego wspólnego święta pozdrawiamy was miłością braterstwa, pozdrawiamy nadzieją przyjacielskiego spółżycia i spółdziania, pozdrawiamy życzeniem, ażeby to błogosławione słońce szczęśliwej przyszłości, które dotychczas przedzierało się tylko blademi i wązkiemi smużkami przez szczeliny ścian naszej i waszej niewoli, oświecało wszystkiemi promieniami nasze i wasze życie”, Monitor Polski 1918, nr 228, Kronika polityczna-społeczna.

44 O ile struktura narodowościowa Bośni i Hercegowiny współmiernie obejmowała narody Chorwatów, Muzułmanów i Serbów, o tyle trudno przypuszczać aby polscy pisarze nie byli wyposażeni choćby w symptomy świadomości o odrębności Czarnogórców i Macedończyków. Warto tu wymienić przede wszystkim działalność Petroviciów-Njegošów po stronie Czarnogóry oraz przedstawicieli tzw. Nowej Macedońskiej Literatury po stronie Macedonii, którzy na przełomie XIX i XX wieku w różnych wymiarach wyposażali swoje narody w atrybuty tożsamości narodowej i poczucie odrębności. 
zaś faktycznie do tego wydarzenia doszło 8 grudnia 1918 roku. Taki stan rzeczy został oficjalnie potwierdzony królewskim dekretem o utworzeniu rządu z 20 grudnia 1918 roku ${ }^{45}$. Ponadto w Monitorze Polskim poinformowano, że premierem został Nikola Pašić, podczas gdy ów serbski mąż stanu od dnia utworzenia Królestwa SHS sprawował „zaledwie” funkcję premiera pełniącego obowiązki, którą formalnie utracił na rzecz przejmującego ster nad rządem Stojana Proticia. Pozostałe informacje zostały podane zgodnie z prawdą, że na urząd wicepremiera rządu został powołany Słoweniec Anton Korošec, zaś tekę ministerstwa spraw zagranicznych otrzymał Chorwat Ante Trumbić ${ }^{46}$. Pomimo iż rząd Proticia upadł 16 sierpnia 1919 roku to kierownictwo nad jugosłowiańskim MSZ aż do 22 listopada 1920 roku sprawował Trumbić, który na tym stanowisku utrzymał się przez cztery kolejne gabinety królewskie.

Tymczasem w okresie ukonstytuowania się centralnych władz w Królestwie SHS polskim resortem spraw zagranicznych w rządzie Moraczewskiego kierował Leon Wasilewski. Jego kadencja w tym ministerstwie była niepomiernie krótsza w odniesieniu do dyplomaty chorwackiego, ponieważ trwała niespełna dwa miesiące. Jednak w okresie kierowania przez Wasilewskiego polskim MSZ w grudniu 1918 roku do Belgradu został wysłany Czesław Pruszyński, który na początku następnego roku objął kierownictwo nad polskim poselstwem w Królestwie SHS. Placówka kierowana przez Pruszyńskiego uruchomiła oficjalną działalność dopiero 16 stycznia 1919 roku. Wtedy bowiem Józef Piłsudski wystosował depeszę notyfikacyjną do księcia regenta Aleksandra ${ }^{47}$. Tego dnia pomiędzy Warszawą a KNP uformował się porozumiewawczy polski rząd, nad którym przewodnictwo objął Ignacy Paderewski, będący jednocześnie następcą Wasilewskiego na stanowisku szefa MSZ.

Równolegle z organizacją polskiego poselstwa na terytorium Królestwa SHS wykształciły się w polskim MSZ plany utworzenia sieci placówek konsularnych. Prace nad nimi zostały rozpoczęte jeszcze pod koniec 1918 roku, ponieważ 12 grudnia 1918 roku kierowany przez Leona Malhomme wydział konsularny MSZ na bazie konsultacji z delegatami wydziału ekonomiczno-handlowego tego ministerstwa oraz ministerstwa przemysłu i handlu utworzył projekt sieci konsularnej. W pracach nad dokumentem zwrócono uwagę na wartość jaką niesie ustanowienie polskich konsulatów w krajach stanowiących atrakcyjny rynek eksportu

45 Dekret został wydany przez księcia regenta Aleksandra w imieniu króla Piotra I.

46 Por. Monitor Polski 1918, nr 230, Telegramy; Ukaz o postavljenju prve vlade Kraljevstva Srba, Hrvata i Slovenaca od 2. decembra 1918, [w:] Jugoslavija 1918-1988..., s. 146.

47 Historia Dyplomacji Polskiej, red. P. Łossowski, t. IV: 1918-1939, Warszawa 1995, s. 13; A. Szczepaniak, Działalność dyplomatyczna Erazma Piltza w Belgradzie (26 VI 1919-20 III 1920), [w:] Między Europa Naszych Pragnień a Europa Naszych Możliwości, red. J. Faryś, T. Sikorski, P. Słowiński, t. II, Gorzów Wielkopolski 2007, s. 227. 
dla Polski. W tym kontekście wymieniono przede wszystkim kraje Bałkańskie oraz Rosję. Wśród planowanych jugosłowiańskich placówek dyplomatycznych zaprojektowano utworzenie konsulatów w takich miastach jak m.in. Fiume, Szkodra, Nisz i Wlora. Twórcy projektu zdawali sobie sprawę z jego tymczasowości i przygotowawczego charakteru. Argumentowano, że: „interesy Państwa Polskiego pod względem ekonomicznym i prawno-państwowym nie są jeszcze dostatecznie ustalone"48. Tymczasem w odniesieniu do stosunków polsko-jugosłowiańskich projekt budził wątpliwości bynajmniej nie ze względu na niejasne interesy Polski. Wszak problemu politycznego nie sprawiał jedynie wybór serbskiego Niszu na ewentualne miasto, w którym mógłby zostać ustanowiony konsulat ${ }^{49}$.

Można odnieść wrażenie, że autorzy projektu utożsamiali Jugosławię z obszarem znacznie większym terytorialnie niż w odniesieniu do granic Królestwa SHS. W projekcie zabrakło wyszczególnienia placówek konsularnych w Albanii, zaś albańskie miasta Szkodra i Wlora zostały przyporządkowane państwu jugosłowiańskiemu. Taki stan rzeczy można uznać za rażącą nieostrożność dyplomatyczną, ponieważ Szkodra w tym okresie była okupowana przez Włochy, zaś w stosunku do Wlory aspiracje wyrażało Królestwo SHS, co zresztą zakończyło się konfliktem jugosłowiańsko-albańskim o Wlorę w latach 1920-192450. Wyjątkowo niefortunnie sformułowano również w tym dokumencie nazwę Rijeki, bowiem polscy urzędnicy zastosowali wobec tego miasta włosko brzmiące określenie Fiume, a to wobec konfliktu Królestwa SHS i Królestwa Włoch mogło zostać zinterpretowane jako wyraz solidarności z państwem króla Wiktora Emmanuela III ${ }^{51}$.

W każdym razie polskie konsulaty, tak jak i poselstwo oraz attachaty wojskowe na terytorium Królestwa SHS rozpoczęły oficjalną działalność w 1919 roku. Wtedy też pracę nad utworzeniem projektu sieci placówek dyplomatycznych w Polsce utworzyli politycy jugosłowiańscy. $\mathrm{Na}$ tej podstawie przeobrażenia listopada i grudnia 1918 roku, w których na omówionych płaszczyznach wykształciły się relacje Polski z Jugosławią należy traktować jako wstępne podstawy budowy wzajemnych stosunków. Procesowi ich kształtowania towarzyszyło

48 [po 12 grudnia], notatka Wydziału Konsularnego w sprawie utworzenia sieci konsularnej, [w:] PDD 1918, s. 233.

49 Ibidem.

50 Ostatecznie Wlora 31 maja 1924 roku została wyzwolona przez Albańskie Siły Demokratyczne. Warto wspomnieć, że to miasto już wcześniej stanowiło obiekt szczególnych zainteresowań przede wszystkim po stronie Królestwa Czarnogóry, które nawet dwukrotnie okupowało Wlorę. Pierwszy raz w kwietniu 1913 roku w okresie wojen bałkańskich, zaś drugi raz od czerwca 1915 do stycznia 1916 roku w czasie pierwszej wojny światowej.

51 [po 12 grudnia], notatka Wydziału Konsularnego..., s. 233-236. 
umacnianie się polskiej i jugosłowiańskiej państwowości w środowisku międzynarodowym, o czym świadczył fakt, że budowa stosunków dyplomatycznych pomiędzy Polską a Jugosławią w 1918 roku przebiegała de facto w trzech etapach. Mianowicie w relacjach pomiędzy Królestwem Polski z Państwem SHS, II Rzeczypospolitą Polską z Państwem SHS oraz wreszcie II Rzeczypospolitą Polską z Królestwem SHS.

\section{Zakończenie}

Mimo, że w okresie międzywojennym pomiędzy Polską i Jugosławią nie zarysowały się priorytetowe obszary współpracy międzynarodowej to w ramach wzajemnych stosunków doszło do zawarcia siedmiu umów dwustronnych w latach 1922-1931, które odnosiły się do szerokiego spektrum współpracy polsko-jugosłowiańskiej obejmującej kwestie polityczne, gospodarcze, kulturowe, oświatowe, prawne, obywatelskie, medyczne oraz konsularne. Państwa współpracowały również w ramach stosunków multilateralnych. Uczestniczyły wszak w procesie zawierania umów podejmowanych w stosunku do byłej monarchii austro-węgierskiej. Pod tym względem w okresie 1922-1925 zawarto w sumie sześć wyspecjalizowanych konwencji, które były związane z kwestiami archiwalnymi, obywatelskimi oraz ekonomicznymi. Stosunki polsko-jugosłowiańskie w dwudziestoleciu międzywojennym znalazły też odzwierciedlenie w pracach Ligi Narodów, a obszar wzajemnej współpracy politycznej rozwinął się również pomiędzy Polską a państwami tzw. Małej Ententy, do której należała Jugosławia ${ }^{52}$.

$\mathrm{Na}$ tej podstawie można zauważyć, że stosunki dyplomatyczne pomiędzy Polską a Jugosławią w okresie międzywojennym cechowały się trwałą współpracą i wymiernymi rezultatami pod postacią zawartych umów prawnych w szerokim zakresie przedmiotowym. Jednak u podstaw budowy tych stosunków znalazły się skomplikowane okoliczności, które były charakterystyczne dla niestabilnego okresu międzynarodowego w ostatnim kwartale 1918 roku. To właśnie w tym okresie odbudowie uległa niepodległa Polska, a także zostało utworzone zjednoczone państwo jugosłowiańskie. Pomimo wielu problemów w osiągnięciu tych wymiarów państwowości Polskę i Jugosławię dosyć szybko połączyły stabilne re-

52 A. Garlicka, Polska-Jugosławia 1934-1939. Z dziejów stosunków politycznych, Wrocław-Warszawa-Kraków-Gdańsk 1977; A. Essen, Polska a Mata Ententa 1920-1934, Warszawa-Kraków 1992; B. Ryś, Rozwój polsko-jugostowiańskich stosunków gospodarczych, Łódź 1986; W. Stępniak, Dyplomacja polska na Batkanach (1918-1926), Warszawa 1998; Ch. L. Wiktor, Multilateral Treaty Calendar: 1648-1995, Hague 1998. 
lacje dyplomatyczne. Należy jednocześnie pamiętać, że już w połowie XIX wieku pomiędzy Polakami a Serbami zawiązała się wspólna oś współpracy, choć przecież wtedy zarówno niepodległość państwa polskiego, jak i ideał jugosłowiański dalekie były nawet od realizacji W ten sposób można zatem mówić o pięknej tradycji polsko-serbsko-jugosłowiańskiej wokół której w 1918 roku dokonywała się rekonfiguracja mocarstwowych układów międzynarodowych. 